\title{
Research Paper \\ Effectiveness of Attachment-Based Intervention Model on Reducing the Parenting Stress in the Mothers of Children with Oppositional Defiant Disorder
}

Seyed Davood Manafi ${ }^{1}$, Mehdi Ghezelseflo" ${ }^{* 2}$, Sajad Hashemi ${ }^{3}$, Behnosh Radpour ${ }^{3}$

1. M.A. in Guidance and Counseling, Abhar Branch of Islamic Azad University, Abhar, Iran

2. Assistant Professor, Department of Psychology, Faculty of Literature and Humanities, University of Gonbad-Kavoos, Iran

3. Ph.D. Student of Counseling, Rodehen Branch of Islamic Azad University, Rodehen, Iran

Citation: Manafi SD, Ghezelseflo M, Hashemi S, Radpour B. Effectiveness of attachment-based intervention model on reducing the parenting stress in the mothers of children with oppositional defiant disorder. Quarterly Journal of Child Mental Health. 2020; 7(1): $233-244$.

\section{http://dx.doi.org/10.29252/jemh.7.1.20}

\section{A R T I C L E I N F O}

\author{
Keywords: \\ Attachment-based, \\ parenting stress, \\ oppositional defiant \\ disorder
}

Received: 30 May 2018

Accepted: 1 Oct 2018

Available: 20 Jun 2020

\section{A B S T R A C T}

Background and Purpose: Children with behavioral disorders display behaviors that may negatively impact on the people and the environment around them and cause numerous problems for their parents and other family members. Therefore, this research was conducted to investigate the effectiveness of an attachment-based intervention model on reducing the parenting stress in mothers of children with oppositional defiant disorder.

Method: This study was a quasi-experimental pretest-posttest control group design with 2-month follow-up. The population included the mothers of all primary school boys with oppositional defiant disorder who had been referred to the consultation center of the Education Administration of Gonbad Kavoos city in 2017. Twenty of them were selected based on the inclusion and exclusion criteria and randomly assigned to either the experimental $(n=10)$ or the control group $(n=10)$. The experimental group received eight 90-min sessions of attachment-based intervention model (once per week), whereas the control group underwent no intervention. Data were analyzed by repeated measures ANOVA.

Results: Findings showed a significant difference between the experimental and control groups in terms of maternal parenting stress $(\mathrm{F}=17.35, \mathrm{P}=0.001)$ and oppositional defiance $(\mathrm{F}=17.65, \mathrm{P}=$ $0.001)$ in the posttest and after two-month follow up.

Conclusion: Maternal attachment therapy provides parents and children psychotherapy centers with effective parenting strategies for improving the functioning of the parent-child relationship and treating the behavioral problems of children suffering from attachment problems.

\footnotetext{
* Corresponding author: Mehdi Ghezelseflo, Assistant Professor, Department of Psychology, Faculty of Literature and Humanities, University of Gonbad-Kavoos, Iran.

E-mail addresses: M.ghezelsefloo@gonbad.ac.ir
} 


\title{
اثربخشى مداخله دلبستكى محور بر كاهش تنيدكى والدينى مادران داراى كود كان مبتلا به اختلال نافرمانى مقابلهاى
}

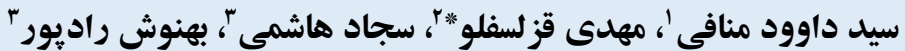

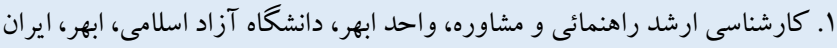

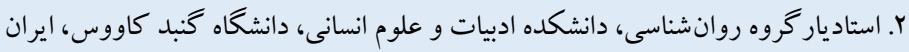

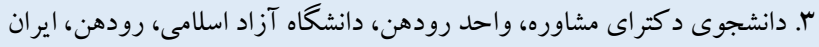

\begin{tabular}{|c|c|}
\hline جكيده & مشخصات مقاله ل \\
\hline زمينه و هدف: كو دكان مبتلا به اختلال هاى رفتارى داراى رفتارهايى هستند كه بر افراد و محيط بيرامونشان، تأثير منفى مى كذارند و مشكلات & كليدوازهها: \\
\hline زيادى براى والدين و ساير اعضاى خانواده خود ايجاد مى كند. در اين راستا هدف يزوهش حاضر، تعيين اثربخشى مدلى از مداخله دلبستكى- & 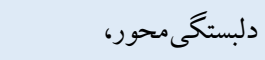 \\
\hline محور بر كاهش تنيدگى والدينى مادران داراى كود كان مبتلا به اختلال نافرمانى مقابلهاى بود. & تنيدگى والدينى، \\
\hline روش: روش بُزوهش نيمه تجربى با طرح ييش آزمون- بِ آزمون با گروه كواه و بيكيرى دو ماهه بود. جامعه آمارى بـزوهش حاضر شامل & نافرمانى مقابلهاى \\
\hline تمامى مادران دانش آموزان بِسر مقطع ابتدايى مبتلا به اختلال نافرمانى مقابلهاى ارجاعى به مركز مشاوره آموزش و يرورش گنبد كاووس در & \\
\hline سال وهَا بود كه ·r نفر از آنها بر اساس ملاككهاى ورود و خروج به مطالعه انتخاب شده و به صورت تصادفى در دو گروه آزمايش (.) & \\
\hline مادر) و گو اه (.1 مادر) جايدهى شدند. كروه آزمايش مدل مداخله دلبستىى محور را به صورت هفتخى در 1 جلسه .9 دقيقهاى دريافت & \\
\hline كردند، ولى گروه گو اه هيج مداخلهاى دريافت نكرد. دادهها با استفاده از آزمون تحليل واريانس اندازه گيرى مكرر تحليل شدند. & \\
\hline 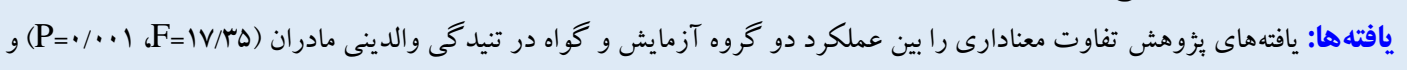 & \\
\hline 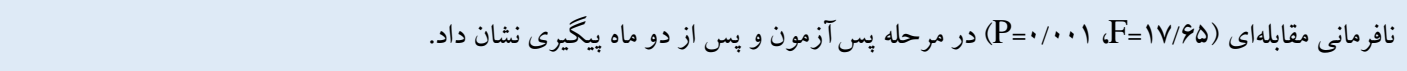 & 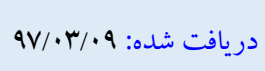 \\
\hline نتيجه كيرى: درمان دلبستخى مادران راهبردهاى كار آمد و سودمندى را براى بهبود عملكرد رابطه والد-كودكك و درمان مشكلات & 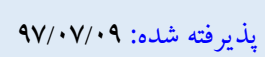 \\
\hline رفتارى كود كانى كه از مشكلات دلبستىى رنج مىبرند، در اختيار والدين و مراكز رواندرمانى كود كان قرار مىدهد. . & 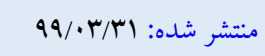 \\
\hline
\end{tabular}

* نويسنده مسئول: مهدى قزلسفلو، استاديار گروه روانشناسى، دانشكده ادييات و علوم انسانى، دانشكاه گنبد كاووس، ايران.

M.ghezelsefloo@gonbad.ac.ir رايانامه

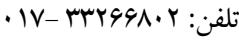


اختلالهاى شـخصيت، حاصل محروميت كودك از مر اقبت مادرانه و يا عدم ثبات رابطه كود كك با جهره دلبستخى است.

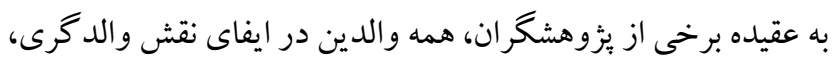

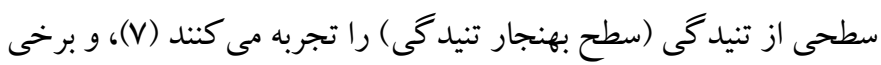

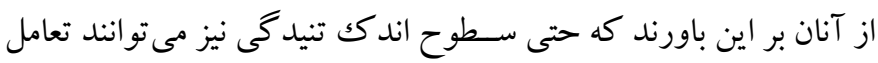

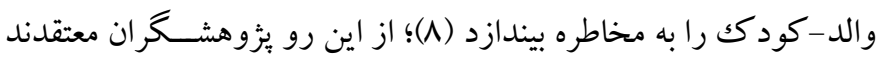
تنيدگى والدگرى ييامدهاى منفى بسيار زيادى داشته و كاركرد مطلوب

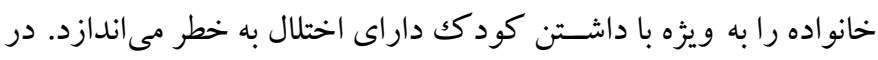
هر صـورت تنيدگى والدگرى، بهعنوان واكنش روانشــناختى ناشسى از

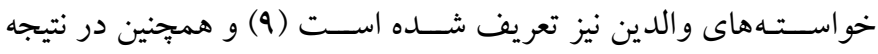
ناهمخوانى ادراكك شــده بين تقاضـاهاى والدگرى و منافع فردى حاصل

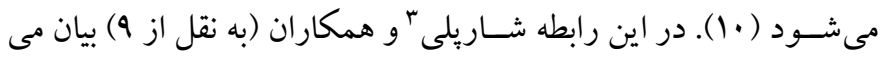

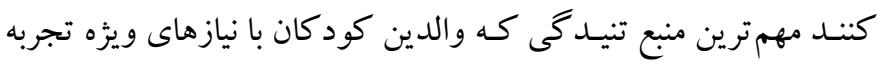

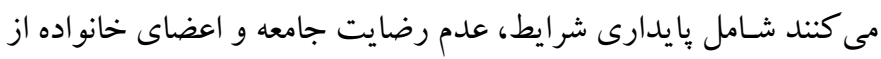
رفتارهاى كودك،، و حمايتهاى حرفهاى ناكافى است. كينگك و نيونهام

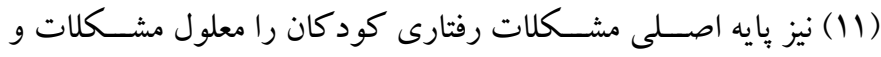
اختلالهاى دلبستخى مىدانند.

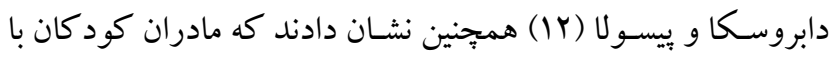

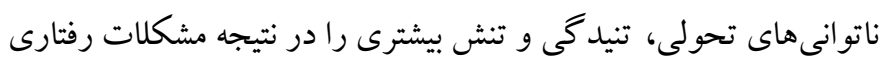
كود كان خود تجربه مى كنند. افزون بر اين، يزوهش ها نشــان دادهاند كه

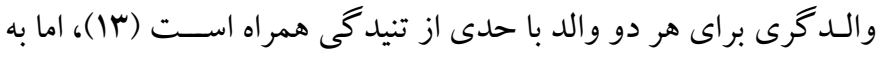

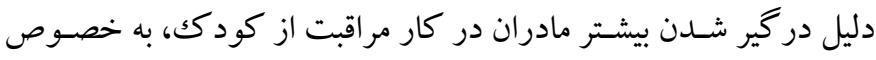

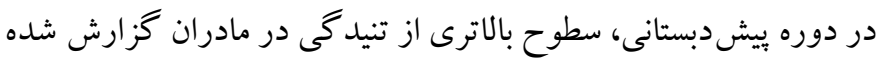

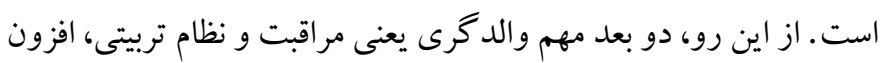
بر ايجاد حس صـلاحيت، مى تواند همراه با دشــوارى هاى ناشسى از اين

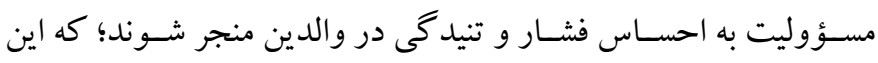

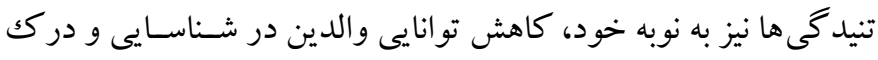

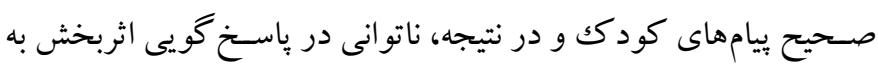
نيازهاى وى رادر يى دارد.
اختلال نافرمانى مقابلهاى 'از شـايع ترين اختلالهاى روانى اسـت كه ميزان

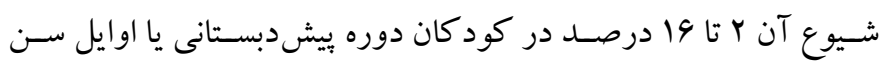

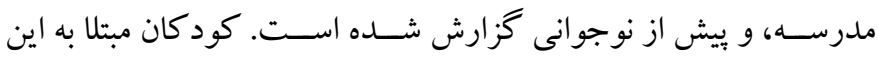
اختلال اساساً در ارتباط با والدين، معلمان، و همسالان دجار مشار مشكل هستند و از نظر قابليت تحصسيلى در سطح بايين ترى از همسالان خود قرار دارند

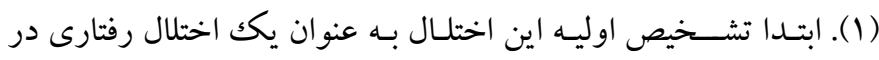

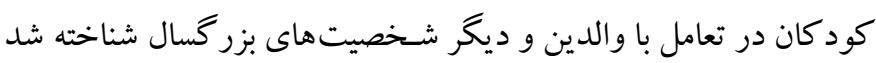

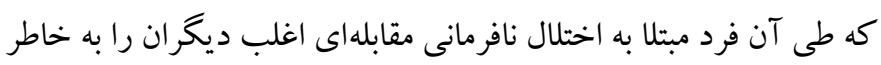
اشـتباهات و سوءرفتارهاى خود مقصر مىداند (Y)؛ بدين ترتيب، ينجمين

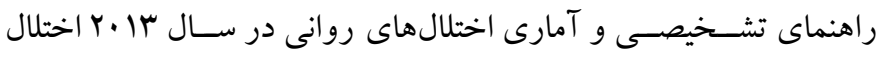

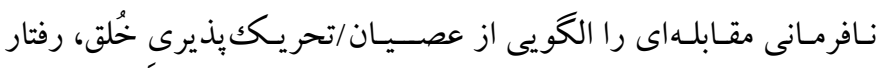

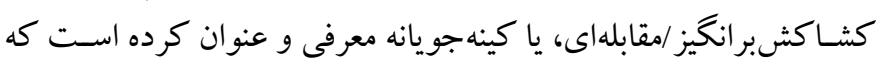
ملاكك هاى اختلال مذكور بايد حداقل هر هفته يكك بار مشـاهده شود و به به

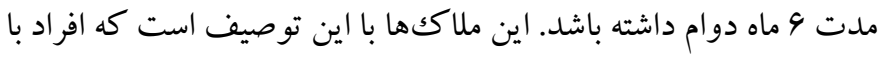

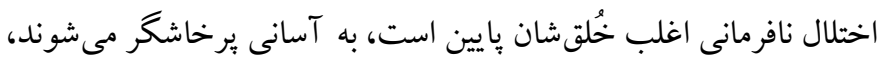

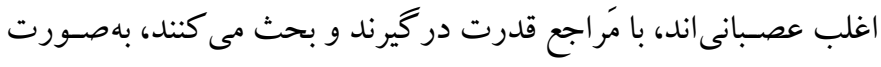

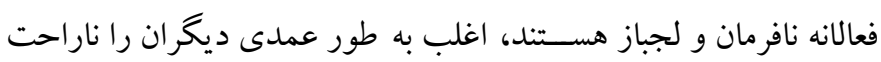

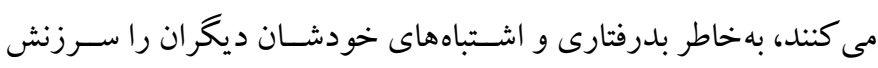

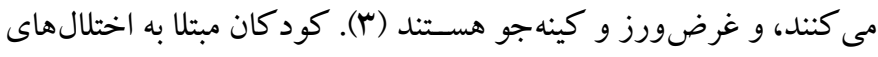

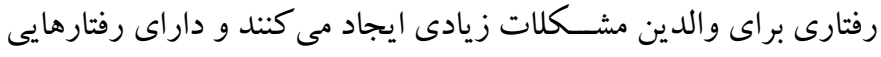

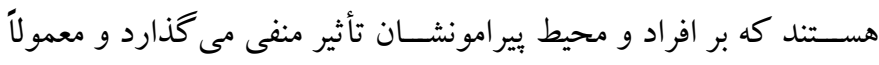

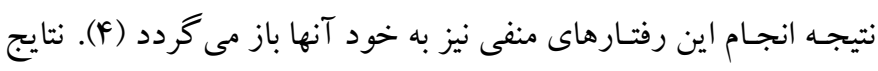

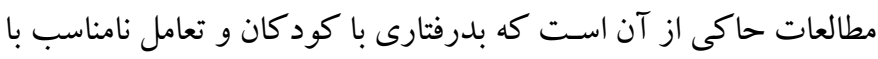

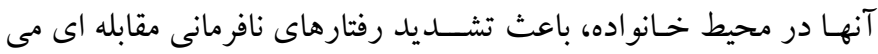

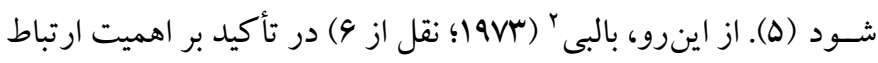

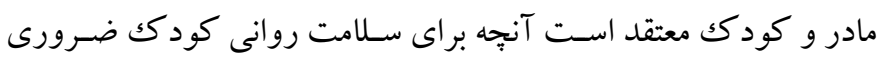
اسـت، تجربه يكك ارتباط گرم، صـميمى، و مداوم با مادر يا جانشين دائم

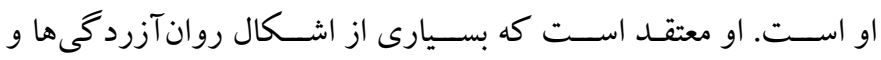


دلبستخى در طول سـالهاى نمويافتخى، نوزادى، دوران كودكى، و

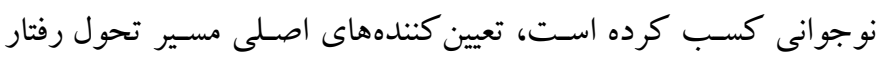

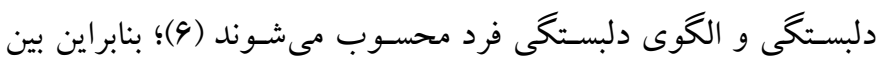

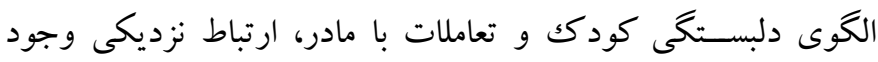

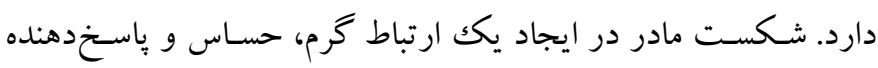

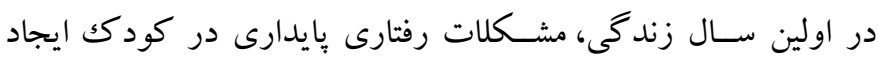

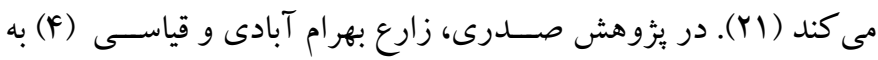

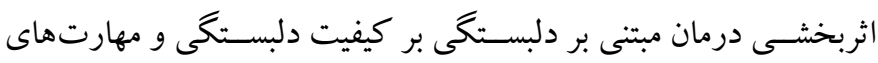

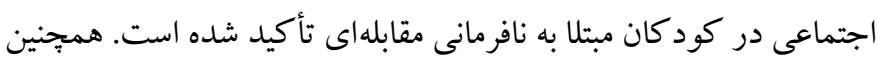

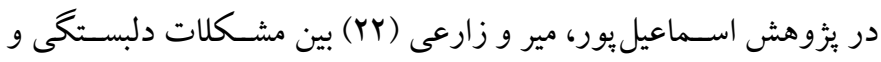

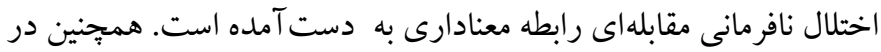

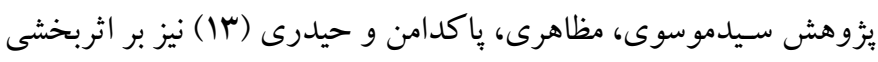

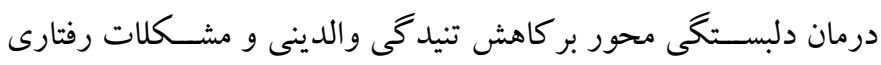

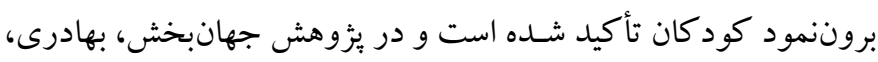
اميرى و جمشـيدى (4) نيز بر اثربخشى درمان مبتنى بر دلبستخى بر علائم

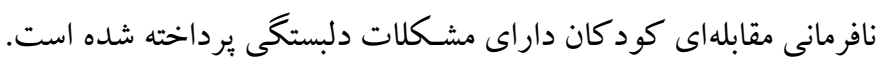

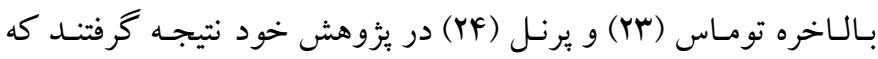

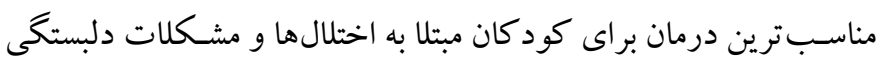

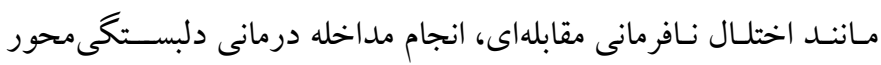

بر اين اسـاس، مدل مداخلهاى يزوهش حاضسر با محوريت عامل

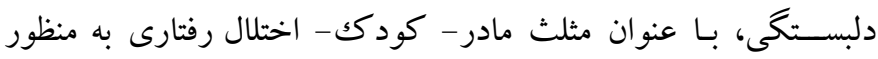
ارزيابى اثربخشى بر بهبود شـاخص هاى سـلامت در كود كان با اختلال نافرمانى مقابلهاى تدوين شـد. مؤلفههاى اساسى مورد ارزيابى و مداخله

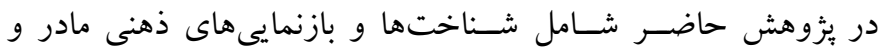
كودكك از سه جزء مثلث مادر - كودكك- رفتار، روابط و اثرات متقابل

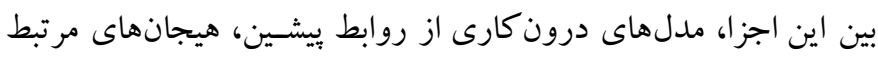

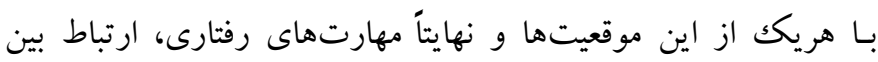
شـخى مادر - كود كى، و سازشيافتكى آنها با مشكل كود كك هستند. بنـابراين هـدف از يزوهش حاضــر تعيين اثربخشـى يكك مدل مداخله

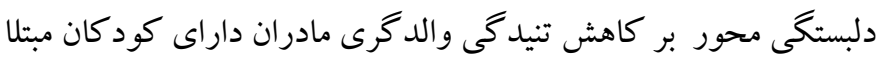
به مشكلات نافرمانى مقابلهاى بود.
تنيدگى مادر به وِاسـخ گويى كمتر، قدرتطلبى، و سـلطهطلبى بيشـتر

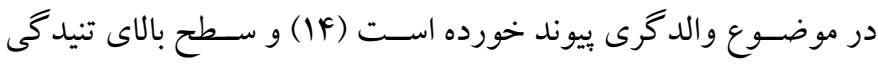

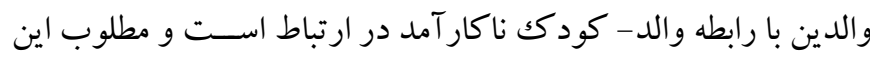
اسـت كه تنيدكى والدين در محدوده طبيعى حفظ شود (ها ). با توجه به واله

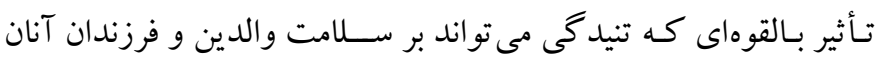

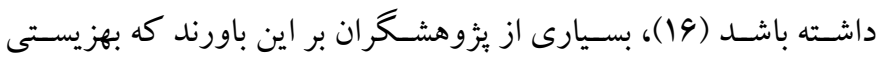

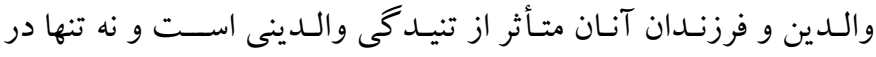

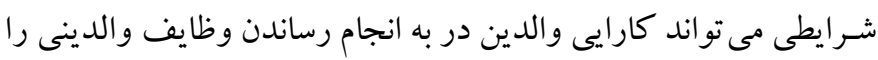

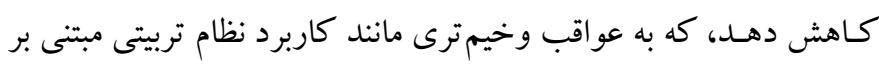

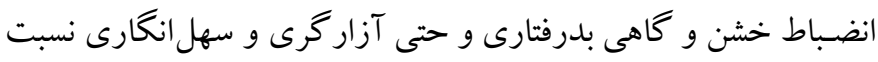

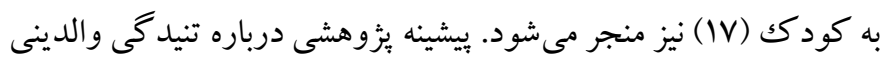

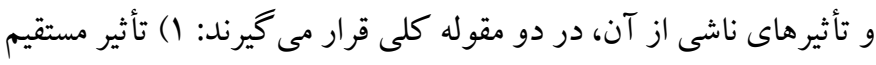

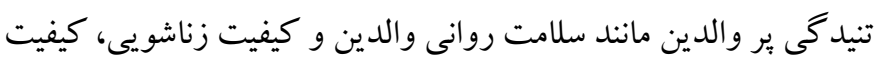

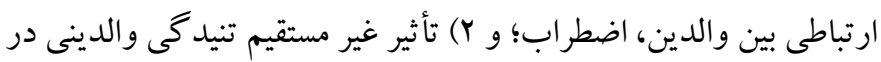

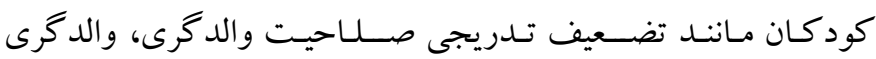
ناكار آمد، كاهش كارايى در به انجام رسـاندن وظايف والدينى، تضعيف

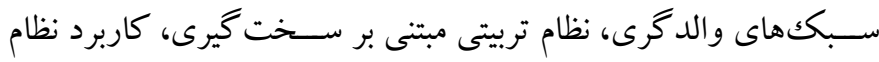

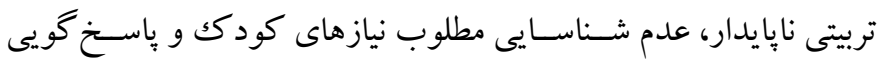

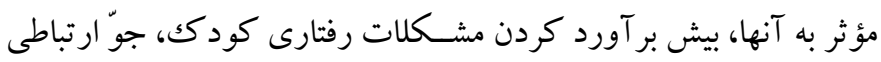
والد-فرزندى فاقد صـميميت، خصسومت نسـبت به فرزندان، و در نهايت

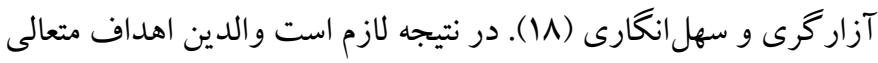
و در عين حال واقع گرايانهاى در مورد رفتار با كود كان خود ترسيم كنند

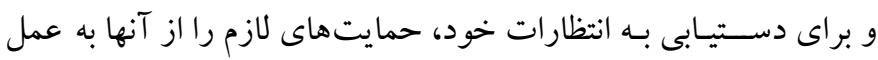
آورند (19). همجنين للازم اسـت والدين براى احساس موفقيت و رسيدن

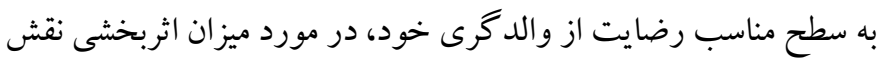

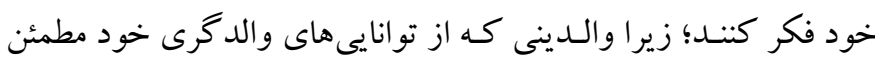

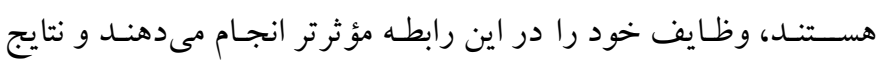
مثبت ترى در تحول روانى فرزندان خود بهدست مى آورند (·r).

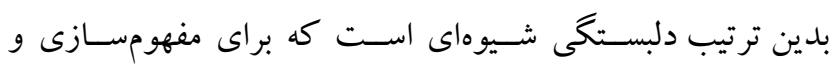
سـنجش كيفيت روابط عاطفى بين دو نفر به كار مىرود و ويز كى بارز

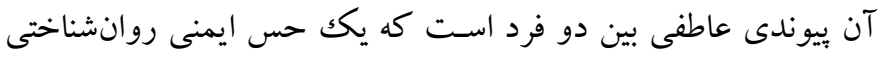

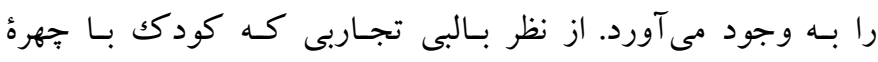


وظسايف والـدينى و همجنين جنبـههـاى منفى آن را مورد توجسه قرار

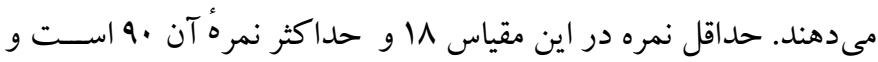

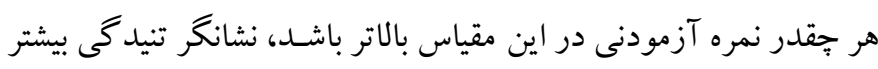

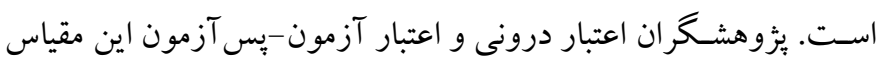

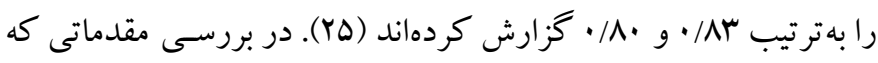

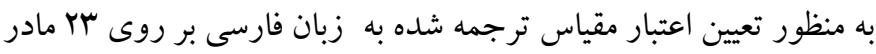

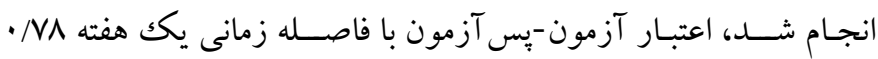

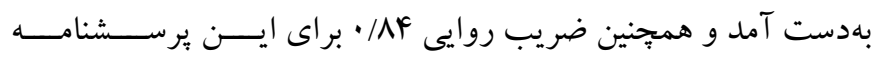

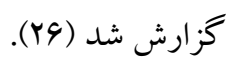

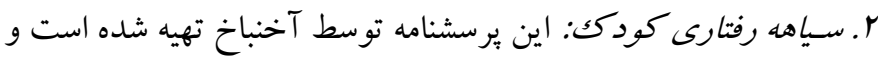
توسط و الدين و يا فردى كه سريرستى كود كك را بر عهده دارد و يا هر

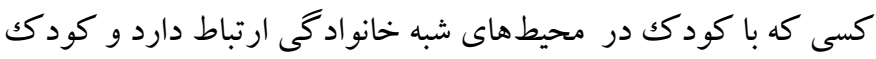

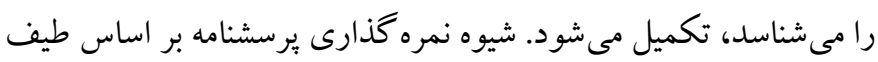

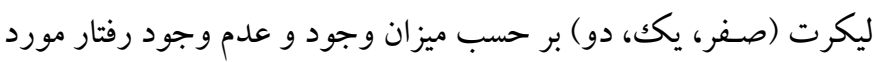

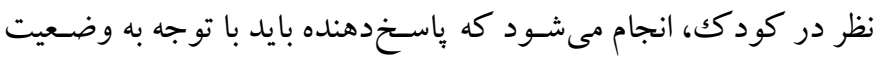

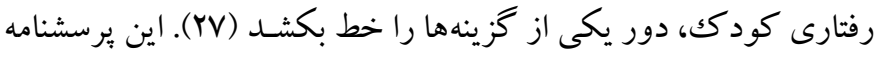

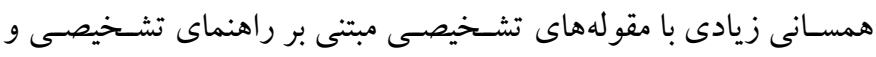

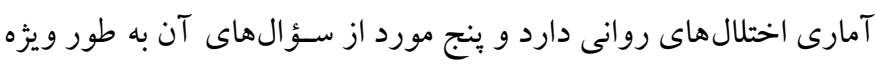

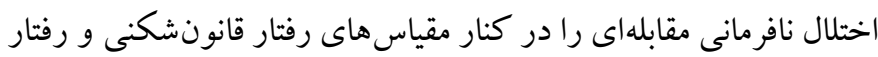

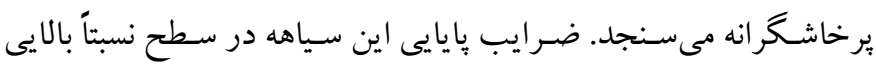

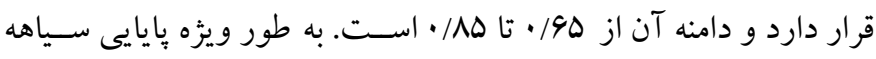

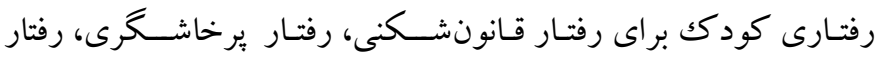

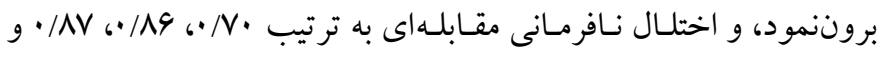

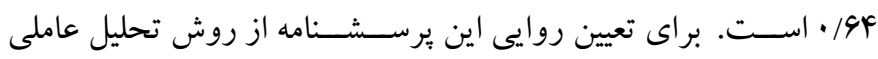

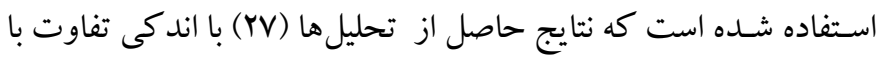

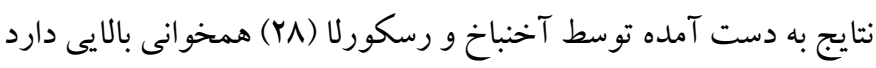

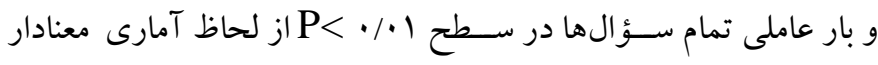

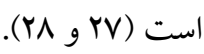
ج) برنامه مداخلهاى: برنامه مداخلهاى در اين مطالعه شامل مدل مداخله

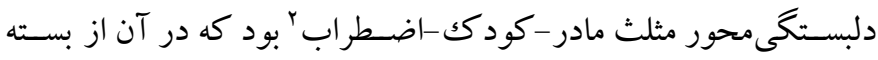

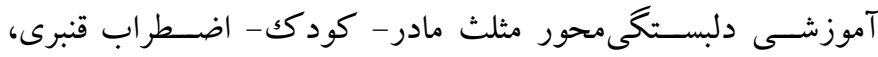

روش الف) طرح يزوهش و شر كت كننـدكـان: اين يُزوهش از طرحهـاى

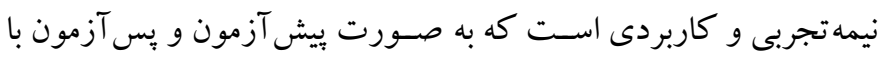

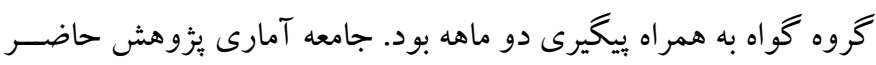

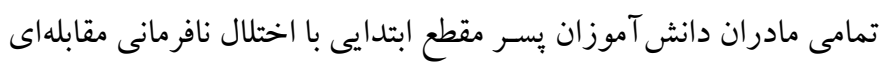

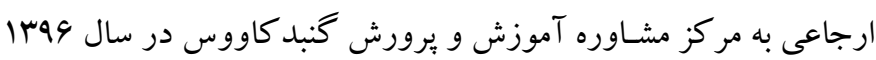
بود كه .r دانش آموزى كه يك انحر اف ماف معيار نمره بالاتر از نمره ميانكين هنجـار مقياس اختلال نافرمانى مقابلهاى (فرم والدين)، كر فتند و همجينين

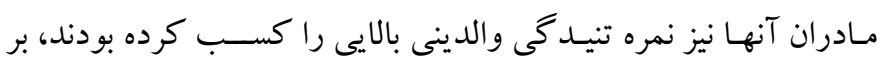

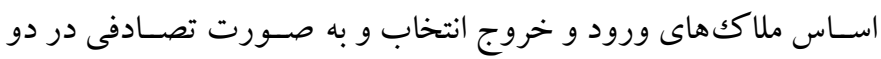

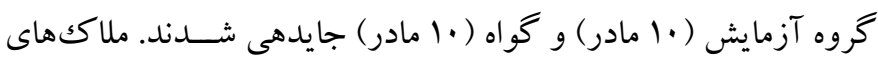
ورود به يزوهش شـامل داشـتن حداقل مدر كك دييلم مادران و رضـايت

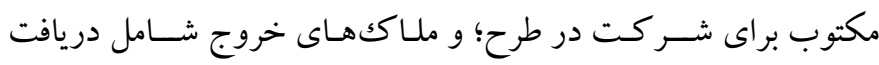
رواندرمانى همزمان با آموزش، مصسرف داروهاى روانيز شـكىى، سـابقه بيمارى روانى، بيمارى جسـمانى بارز، و غيبت بيش از دو جلســه مادران

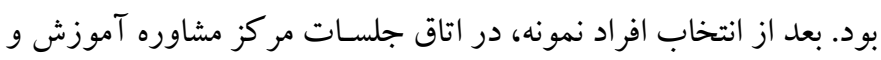

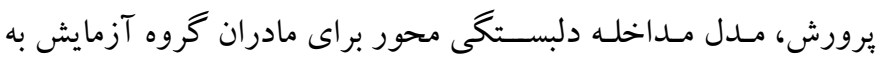

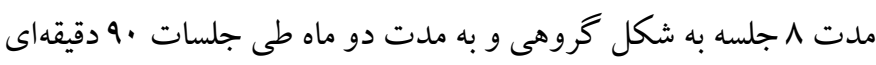
(هفتهاى يكك جلسه) اجرا شد.

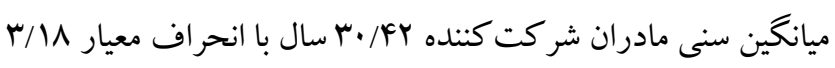

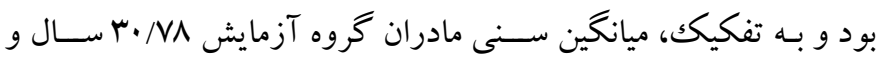

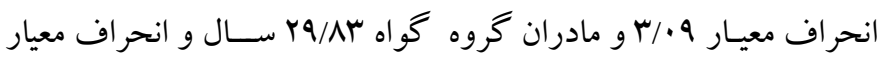

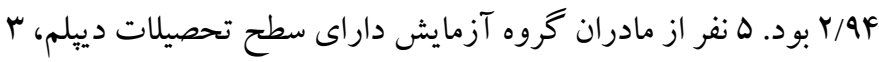
نفر داراى سطح تحصيلات فوق دييلم، و ب نفر داراى سطح تحصسيلات

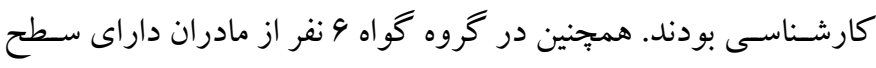

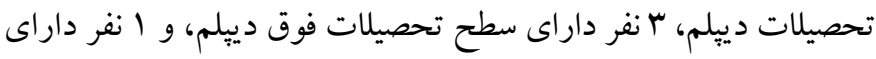
سطح تحصيلات كارشـناسى بود. از نظر وضعيت اقتصادى همه مادران شركت كننده در طبقه متوسط قرار داشتند. ب) ب ابزار

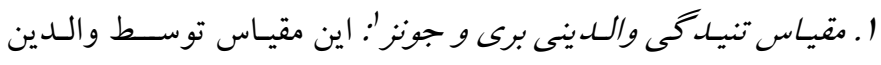

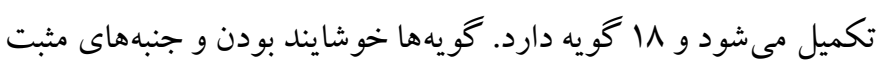


آوردن تصـويرى واقعى و كامل از يكك رابطه اطمينانبخش بين مادر-

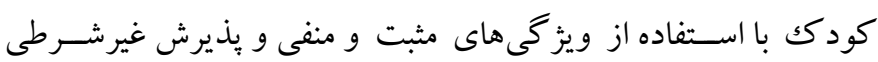
كود كان، آموزش للازم ارائه شد.

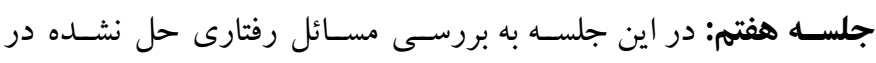

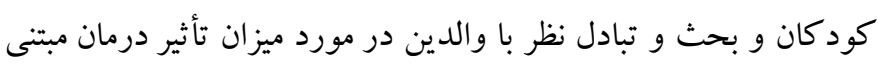

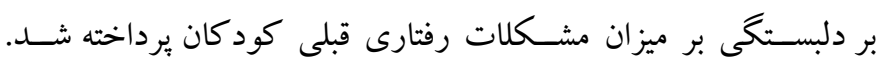

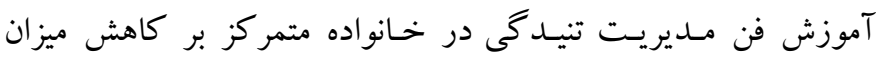

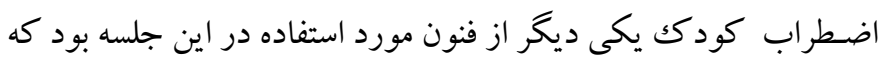

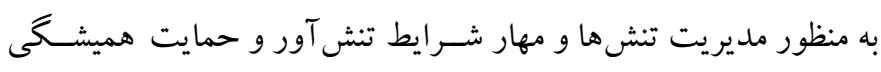
والدين از كودك بِ برداخته شد. جلسـه هشتم: در اين جلسه يس از مرور اجمالى جلسات قبلى، به توجيه

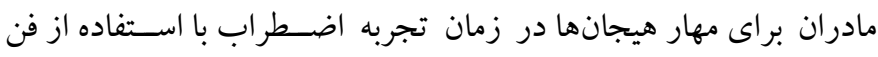

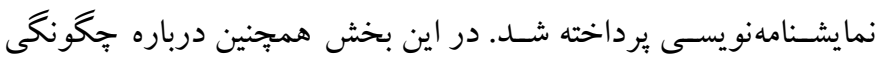

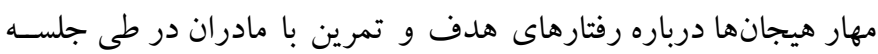
كروهى برداخته شد.

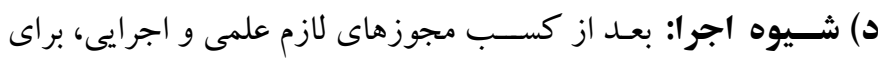

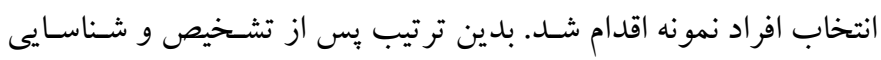

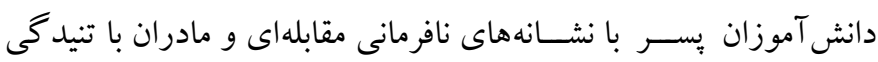

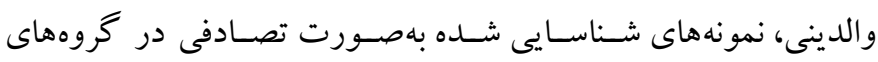

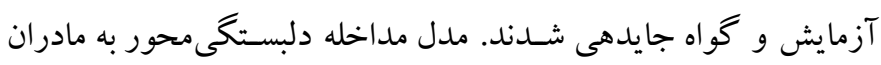

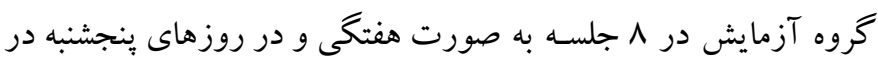

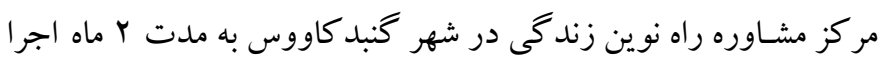

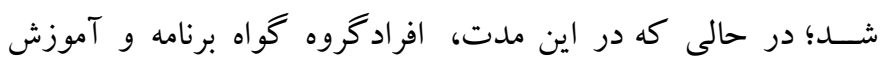

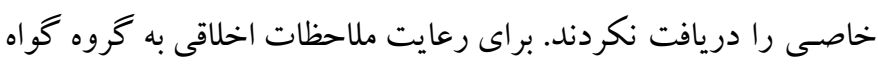

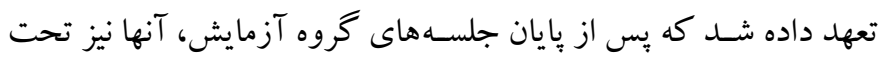

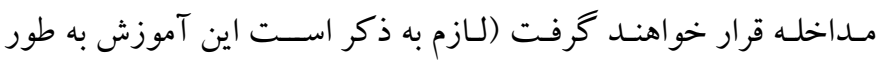

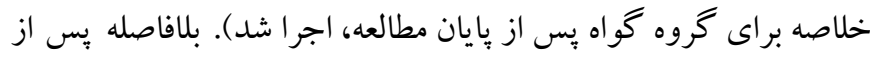

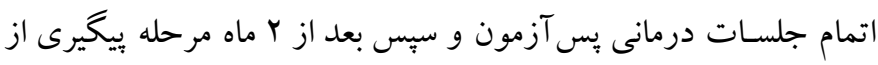

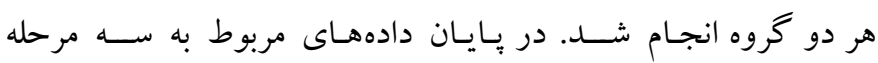

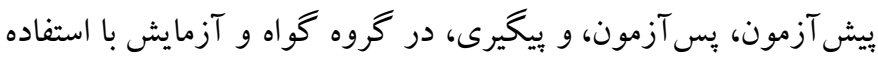

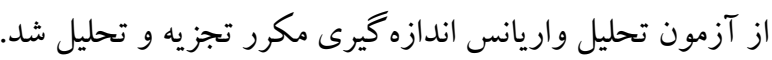

خدايناهى، مظاهرى و غلامعلى لواسـانى (Yq) در م جلسـه .9 دقيقهاى (هر هفته يكك جلسـه) استفاده شـد. خلاصه محتواى جلسات بدين شرح بوده است: جلسـه يكم: در اين جلسه پِ از معارفه اجمالى و آشنايى اعضاى گرُوه

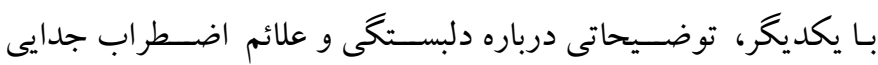

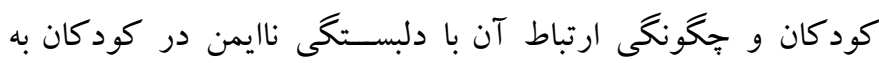

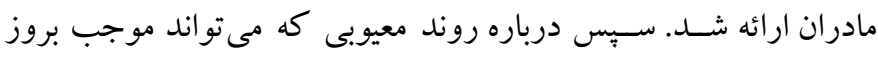
اضطر اب جدايى در كودك شود، توضيحاتى ارائه شد.

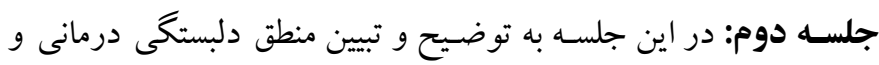

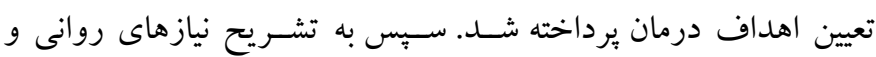
جسمانى كودك و لزوم باسـخدهى به نيازها از سوى مادر با استفاده از

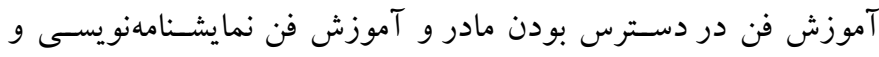
تمرين آن در طول جلسه برداخته شد. جلسـه سـوم: در اين جلسـه بس از مرور جلسـه قبلى، به تشريح اهميت ارتباط كلامى مثبت مادر و كودكك در تحول عاطفى و هيجانى بهنجار

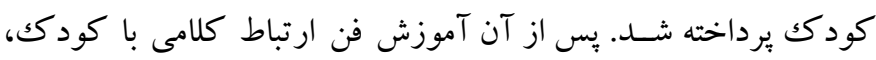

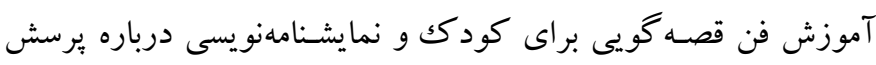

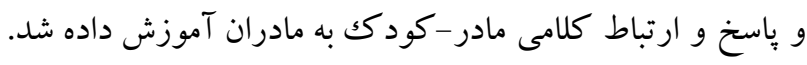

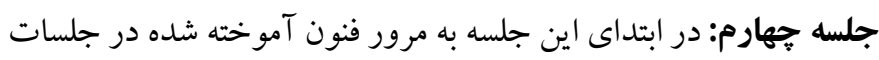

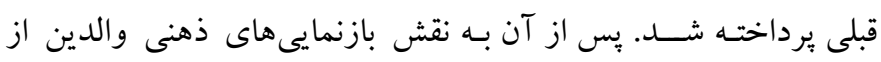

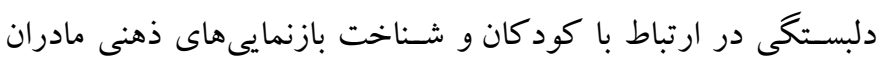

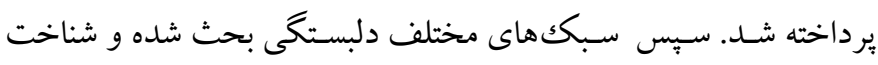
رفتارهاى دلبستخى و اكتشافى در كود كان مرور شد. جلسـه هنجم: در ابتداى اين جلسـه به بحث و بررسى درباره نشـانه هاى

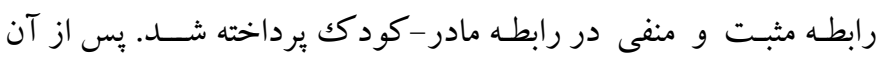

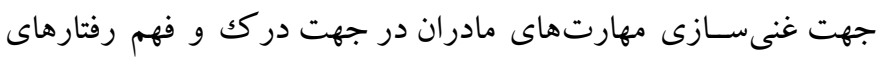
كود كان و انعكاس احسـاسـات درونى خود و توانيى به كلام در آوردن منائ آنها توضيح داده شد. جلسـه ششم: با مرورى بر اقدامات جلسات قبلى، در اين جلسه به ايجاد

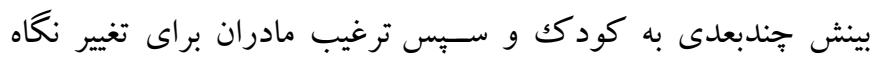

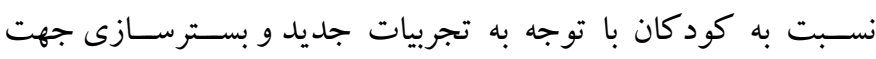

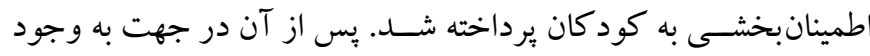


يافتهها

در جدول ا،شـاخص هاى توصسيفى مربوط به متغيرهاى مورد مطالعه در

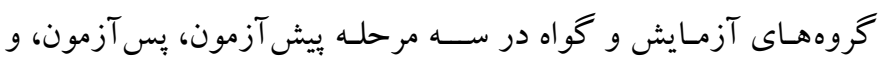

بيكيرى گزارش شده است.

جدول 1: دادههاى توصيفى نمرههاى تروه آزمايش و كواه در سه مرحله ييش آزمون، بس آزمون، و ييكيرى

\begin{tabular}{|c|c|c|c|c|c|c|c|}
\hline \multicolumn{2}{|c|}{ بيعيرى } & \multicolumn{2}{|c|}{ يسآزمون } & \multicolumn{2}{|c|}{ بيش آزمون } & \multirow[b]{2}{*}{ كروه - اه } & \multirow{2}{*}{ شاخصهاى آمارى } \\
\hline انحراف معيار & ميانكين & انحراف معيار & ميانكين & انحراف معيار & ميانكين & & \\
\hline$r / r$. & $r \mu / 4$. & $\mu / \mu$. & $r T / N$ & $r / V V$ & $F \cdot N$. & آزمايش & تنيدگى والدينى \\
\hline r/9r & $\forall / / \Delta$. & r/Q1 & $r \mid N$. & r/QY & Fl/a. & 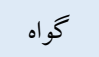 & \\
\hline $1 / 49$ & $r \cdot / \Lambda$. & $1 / T V$ & $r / 1$. & $|/ N|$ & YN/9. & 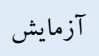 & نافرمانى مقابلهاى \\
\hline T/FY & $\mathrm{rV} / \mathrm{s}$. & $r / \Delta)$ & $\mathrm{rV} / \mathrm{s}$. & $r / T)$ & rV/r. & كواه & \\
\hline
\end{tabular}

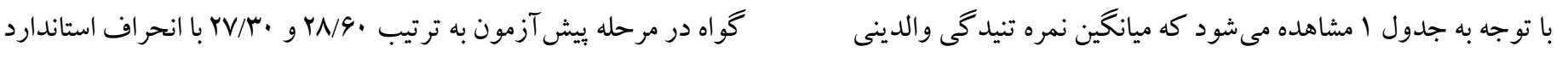

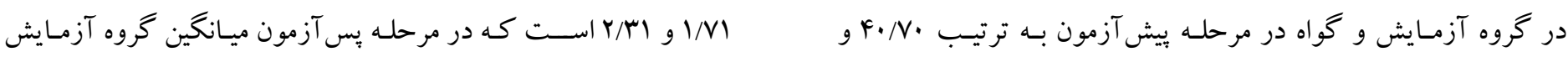

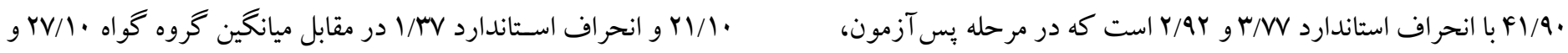

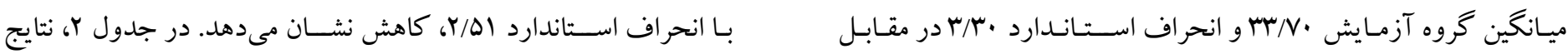

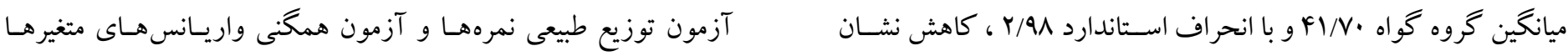

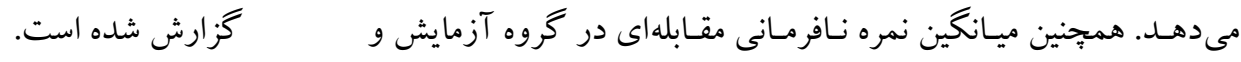

جدول r: نتايج آزمون توزيع طبيعى نمرهها و آزمون همكنى واريانسهاى متغيرها

\begin{tabular}{|c|c|c|c|c|c|c|c|c|c|c|}
\hline \multicolumn{3}{|c|}{ موخلى W } & \multicolumn{3}{|c|}{ آزمون لوين } & \multicolumn{3}{|c|}{ آزمون شاييرو ويلك } & \multirow[b]{2}{*}{ كروه } & \multirow[b]{2}{*}{ متغير } \\
\hline سطنادارى & آماره & 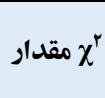 & معنادارى سطح & آماره & آزادى ب & سعنادارى & آماره & آزادى درجه & & \\
\hline.$/ r$. & $\cdot / 19$ & $r / r \Lambda$ & $\cdot N F$ &.$/ 11$ & 11 & $\begin{array}{l}\cdot / 11 \\
. / A r\end{array}$ & $\begin{array}{l}. / 19 \\
. / 99\end{array}$ & $\begin{array}{l}1 . \\
1 .\end{array}$ & كواه & تنيدگى والدينى \\
\hline .1 .9 & . /v & F/NG & $\cdot / r r$ & $1 / \Delta V$ & 11 & $\begin{array}{l}\cdot / \Delta F \\
\cdot / A \mid\end{array}$ & $\begin{array}{l}. / 94 \\
. / 99\end{array}$ & $\begin{array}{l}1 . \\
1 .\end{array}$ & كوزاه & نافرمانى مقابلهاى \\
\hline
\end{tabular}

مفروضـــه كُرويست اســـت؛ بنـابراين مى توان از نتيجـهـ آزمونهـاى

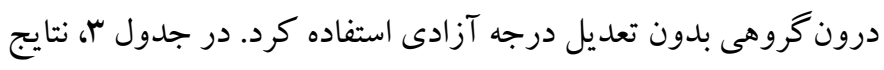

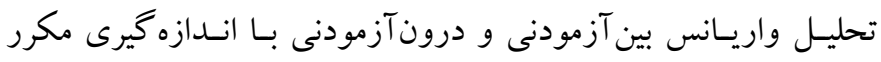
كزارش شده است.

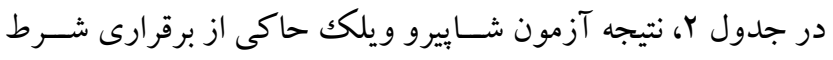

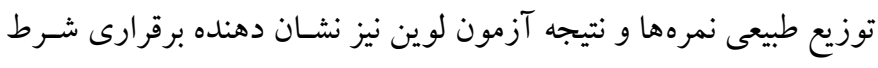

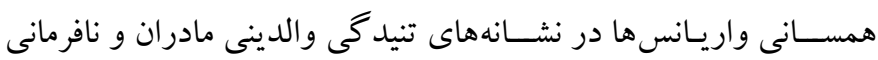

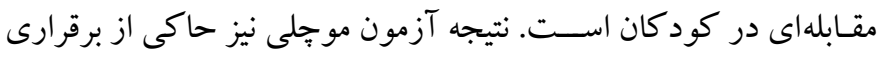


جدول بّ: نتايج تحليل واريانس بين آزمودنى و درون آزمودنى با اندازهكيرى مكرر

\begin{tabular}{|c|c|c|c|c|c|c|c|c|c|}
\hline تزان & اثدازه & معنادارى سطح & $\mathbf{F}$ & مجذوروات & درجادى & مجذورات & & & متغير \\
\hline $1 / \cdot \cdot$ &.$/ 9$. & $\%$ & $19 Y / Y$. & $9 Y / A 1$ & $r$ & $\mid \wedge \Delta / 9 \pi$ & مرحلهى ارزيابى & درونگروهى & \\
\hline $1 / \cdot$ & $\cdot / M$ &.$/ \cdots$ & $149 / 91$ & $V N / Y I$ & r & $109 / 4 T$ & ارزيابى * كروه & & تنيدگى والدينى \\
\hline.$/ 9 V$ & $\cdot / 4 q$ &.$/ .1$ & IV/TL & FqA/AI & 1 & $\mathrm{rqA} / \mathrm{Al}$ & كروه & بين گروهى & \\
\hline $1 / \cdot$ &.$/ 9 F$ & $\cdot / \cdots$ & YAI/AT & $1 \cdot Y / A 1$ & r & $r \cdot \Delta / 9 r$ & مرحلهى ارزيابى & درونگروهى & \\
\hline $1 / \cdot$ & . & $\cdot \cdots$ & ror/AV & $\| \Delta / Y F$ & r & $M \Delta \Delta / Y r$ & ارزيابى ** كروه & & نافرمانى مقابلهاى \\
\hline$\cdot / 9 V$ & $\cdot / 4 q$ &.$/ .1$ & $1 V / 90$ & $r \cdot 1 / 99$ & 1 & $r .1 / 99$ & غروه & بين گروهى & \\
\hline
\end{tabular}

فردى در بهبود رابطه والد-كود كك در مادران از طريق متغير آزمايشى قابل

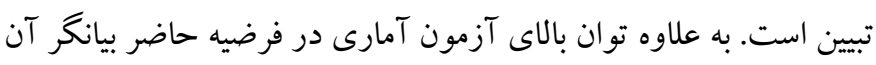

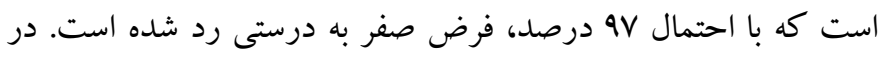
جدول \& نتايج آزمون تعقيبى بن فرونى در سه مرحله در سه مرحله بيش -

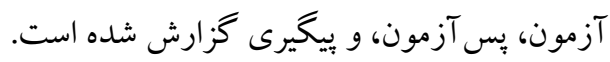

بر اساس نتايج جدول r سطح معنادارى تحليل واريانس آزمون

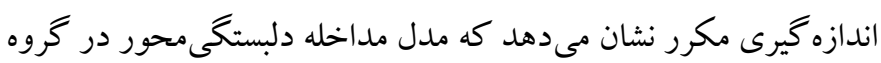

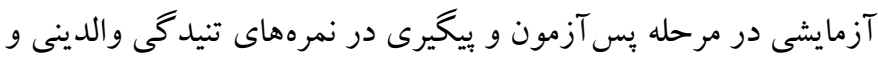

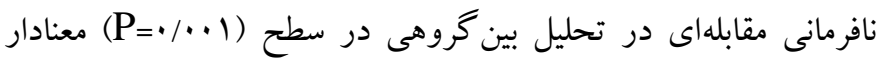

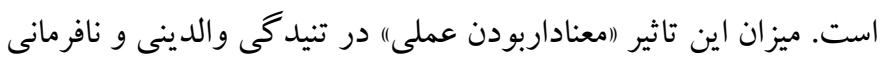

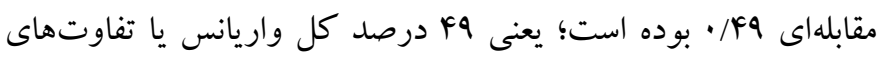

جدول ع: نتايج آزمون تعقيبى بنفرينى در سه مر حله ييش آزمون، بسآزمون، و يبيكيرى

\begin{tabular}{|c|c|c|c|c|c|c|c|c|c|}
\hline \multicolumn{3}{|c|}{ بيش آزمون- يس آزمون } & \multicolumn{3}{|c|}{ بيش آزمون- بيعيرى } & \multicolumn{3}{|c|}{ يس آزمون- ييگيرى } & \multirow[t]{2}{*}{ شاخصهاى آمارى } \\
\hline معنادارى سطح & انحراف & تفاوت ميانتين & معنادارى سطح & انحراف & تفاوت & معنادارى سطح & انحراف & تفاوت & \\
\hline .194 & $\cdot / 19$ & $\cdot / r \Delta$ & $\cdot / \cdots$ & $\cdot / r V$ & $\Gamma / \Lambda \Delta^{* * *}$ & $\cdot / \cdots$ & $\cdot / Y F$ & $r / 9 \cdot{ }^{* * *}$ & تنيدگى والدينى \\
\hline.$/ 99$ &.$/ 10$ &.$/ 10$ & $\cdot / \cdots$ & Tr/ & 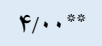 & $\cdot / \cdots$ & $\cdot / 1 \wedge$ & $\Gamma / \wedge \Delta^{* \% *}$ & نافرمانى مقابلهاى \\
\hline
\end{tabular}

است نتايج حاصل در مرحله بيخيرى باز گثت نداشته و اثر مداخله بِايدار

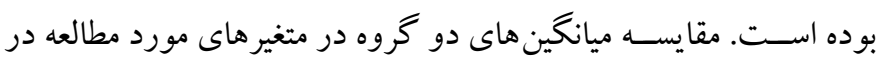
نمودارهاى او ب نيز ارائه شده است.

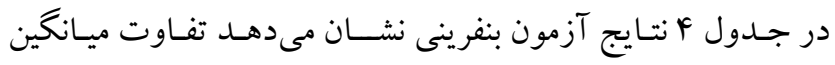

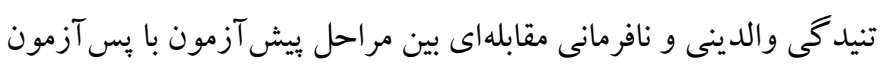

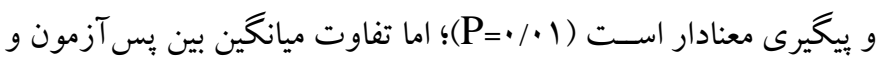

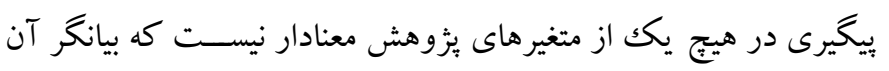




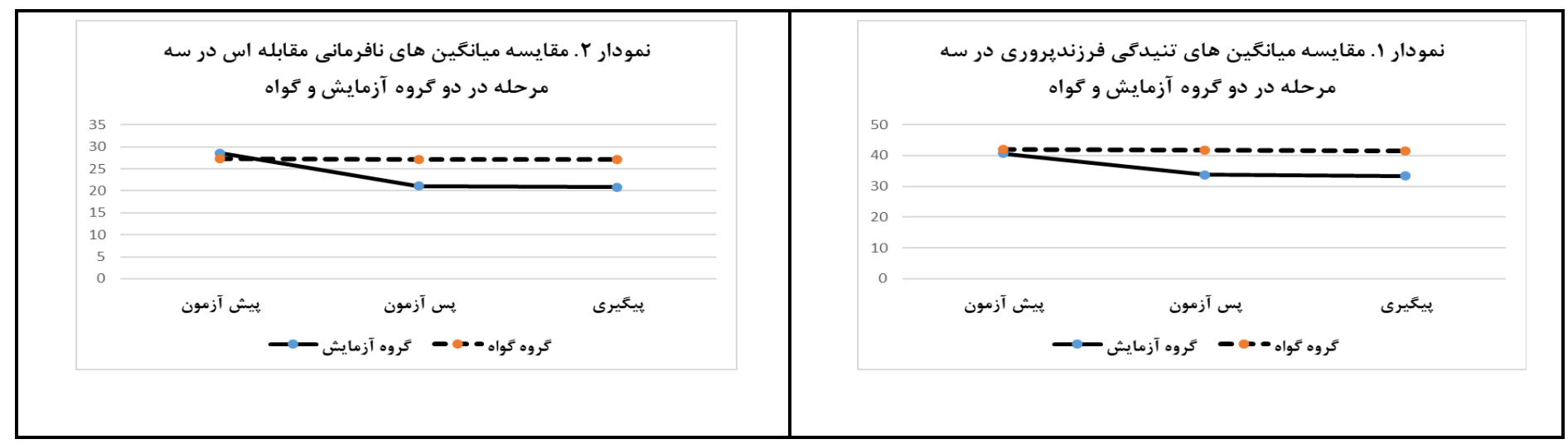

نمودارهاى ا و זّ: اثربخشى مدل مداخله دلبستى محور بر تنيدگى والدينى مادران و نافرمانى مقابلهاى

حسـاسيت مادر به واسطه آموزش هاى داده شده مىتواند موجب كاهش احســاس كناهكـارى در وى شود و در نتيجه افسردگى ناشى از تنيدگى

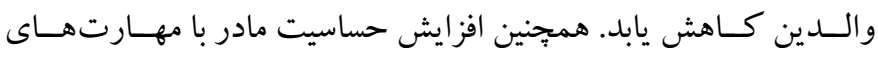
تنظـيم هيجــانى بهتــر در كـود كك همــراه بــوده و اين موجب كاهش مشكلات خلقى كودكك نيز مى شـود (IY). همجينين بـايسـ توجه داشــت كه افزايش توانايى مادر در دركك علل رفتارهاى منفىى كـودك و مهار آنها، همراه با بهبود كيفيت تعامل مادر كودك موجــب احسـاس صـلاحيت بيشـتر مـادر در حـل مشكلات و نقـــش والدينى خويش مى شـود. از اين رو، فقدان نظارت خانوادكى و عدم شكل گيرى صحيح رابطههاى مبتنى بر دلبستكى، مهمترين عامل در ايجاد مشكلات رفتارى است و والدين اين افراد در مقابل فرزندان خود، واكنش هـاى غيرقابل بيشبينى و ناهمســان داشـتند (f). ارتباط والدكودك نيز بــون وجود اعتمـاد كـامل دو طرفه، ارتباط ايمن و مطلوبى محســوب نمى شــود و نتيجـهـ آن جيزى بـه جز رفتـارهـاى مقـابلهاى و منفى كارانه كودكك در برابر مادر نخواهد بود. عدم تصحيح اين ارتباط و

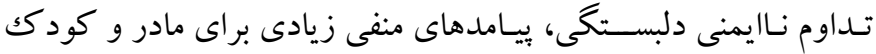
خواهـد داشــت (19). مطـالعـات جـديد نشــان مى دهند كه نافرمانى و رفتارهاى منفى گر ايانه كود كان تا حد بسـيار زيادى با ناليمنى دلبستكى و ارتبـاط نامطلوب والد-كودك در ارتباط اســت (F). در تأييد اين نكته كينگك و نيونهام (11) نيز بايه اصلى مشكلات رفتارى كود كان را معلول مشكلات و اختلالهاى دلبستكى مى دانند و معتقدند كه درمانهاى مبتنى بر دلبستكى به بهبود تعاملات والد-كود كى كمكك مى كنند. درمان مبتنى بر دلبسـتگى با به كارگرفتن فنونى مثل آموزش در دسـترس بودن مادر،
همان گونه كه درنمودارهاى ا و Y نشـان قابل مشـاهده است تنيدگى

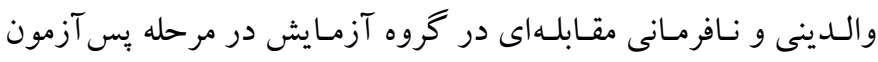
كاهش داشته و اين كاهش در مرحله بيگيرى نيز بايدار مانده است؛ ولى در گروه گو اه تغييرى مشاهده نمىشود.

\section{بحث و نتيجه Fيرى}

مطالعه حاضر با هدف تعيين ميزان اثربخشى مدل مداخله دلبستكى محور بر تنيـدكى والـدينى مـادران داراى كودكـان مبتلـا بـهـ نـافرمانى مقابلهاى انجام شـد. يافتهاى يثزوهش حاضـر، حاكى از بهبود تنيدكى والدينى مادران، و نافرمانى مقابلهاى كود كان آنها در گروه آزمايش در مقايسـه با گرووه گواه در مرحله يس آزمون بود و اين بهبودى در طول زمان

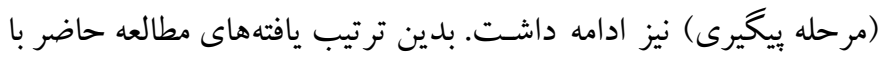
نتـايج يزوهش هاى صــدرى و همكاران (F)، اســماعيل يور و همكاران (YY)، سيدموسوى و همكاران (YI)، جهانبخش و همكاران (9)، توماس (YY) و يرنل (YY) همسو است. در يُزوهش حاضر تـلاش شــد تـا دانش مـادر از نيـازهـاى ارتباطى و هيجانى كود كك افزايش يابــــــــ و مادر به ياسخخهـاى كار آمسـدترى در ارتبـاط بـا رفتـار منفىى كودك، دست بيدا كند. از سوى ديخر، با افزايش بيـنش مـادر از انخيزههاى زيربنـايى رفتـار كـــودك و همجنــــن شــناخت فر ايندهاى دفاعى خويش در ارتباط با كود ك، انتظــــار مــــىرود يذيرند

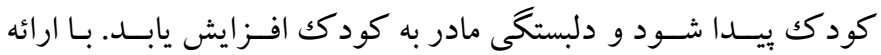
ياســخ هــاى مناسب از سوى مـادر، كـود كـ نيـز كم كم بـه دادن ياسـخخ عاطفى مثبت نسبت بــه مــادر كـــايش بيــدا مــى كنــد و ايــن موجب افـزايش تقويست گــــى ميــان آنها مــىشـود (F). علاوه بر آن، افزايش 
خطى مادر- كودك، سيستم تعاملى و دلبستكى مادر و كودكى را در

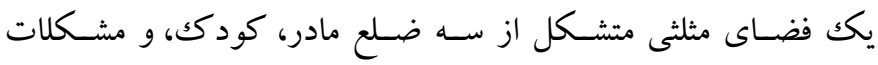

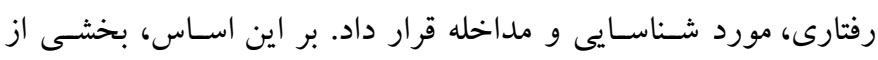

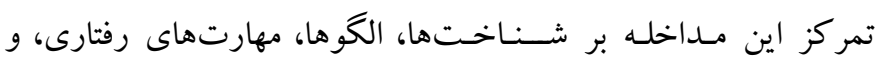
هيجانهاى مادر-كودكى درباره مشكلات رفتارى كودكك بود. در ئزوهش حاضسر باوجود تلاش جهت كنترل عوامل احتمالى مالى

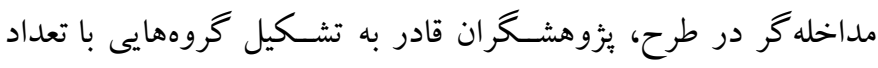

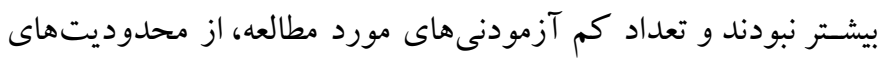

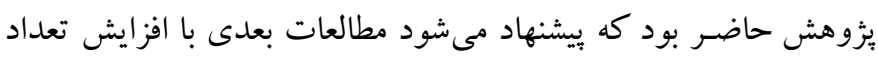
آزمودنىها، به ارزيابى دقيقتر اعتبار اين روش در بهـبود بهدود رابطه والدهكودك و كاهش تنيدگى مادران و سطح نافرمانى مقابلهاى كود كان آنها

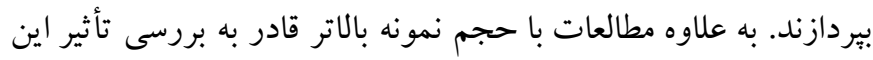

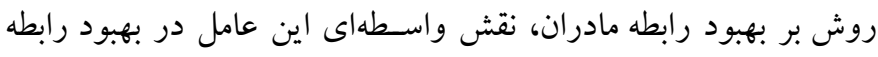

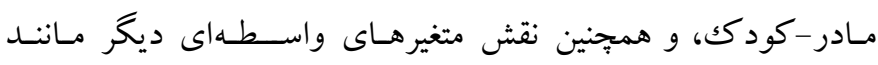

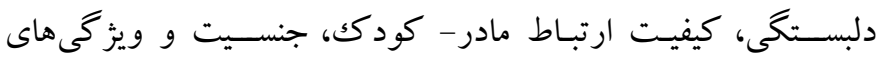
روانشـناختى مادر و كودكى خواهد بود. للازم به ذكر اسـت يزوهش

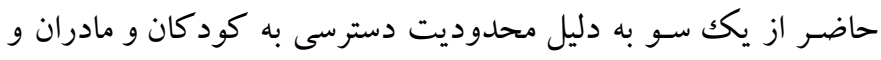

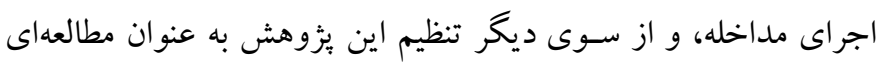

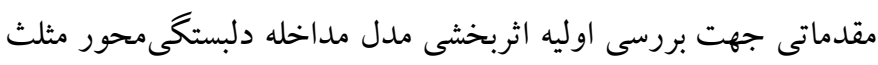

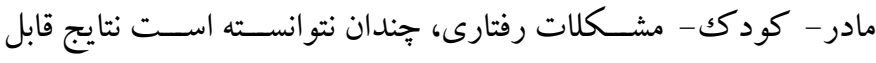

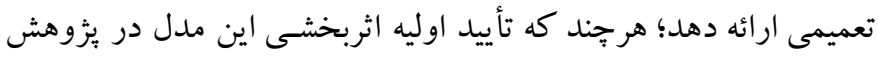

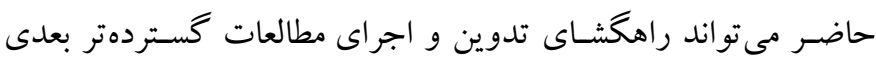

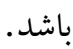

تشكر و قدردانى: اين مطالعه به صورت مستقل اجرا شده است و حاصل بايان

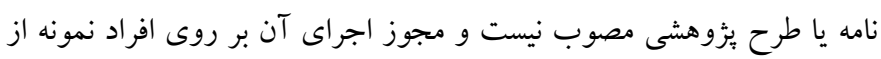

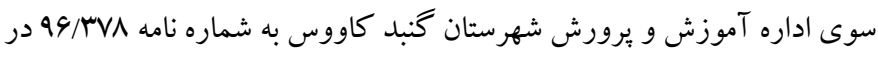

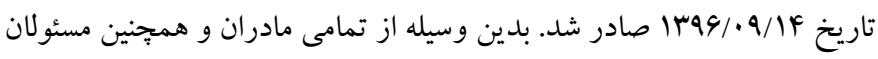

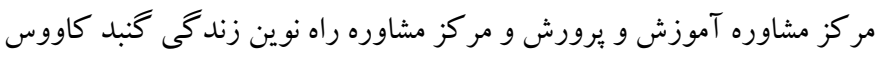

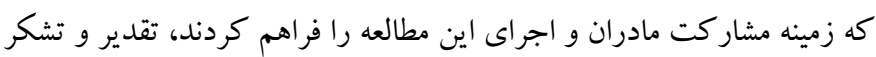

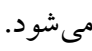

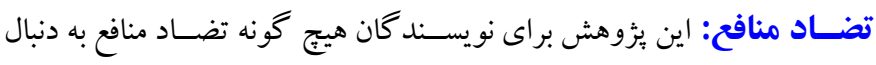

تأمين نيـازهـاى فيزيولوزيـكك و روانى كودك، تـأمين امنيـت كودكى،

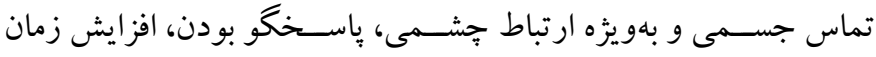

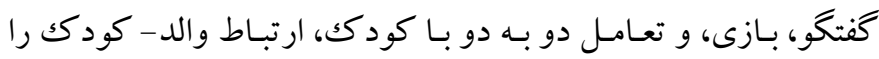

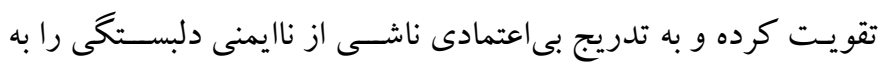

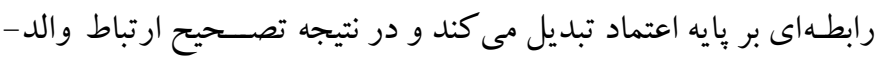

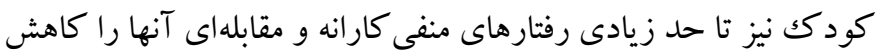

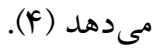
مدل مداخله دلبستِكى محور مذكور با تكيه بر مبانى نظرى بيشـين،

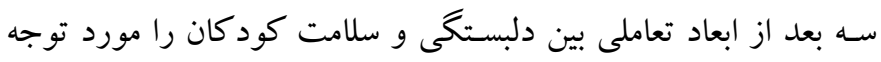

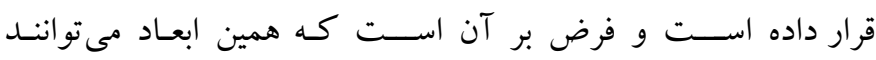

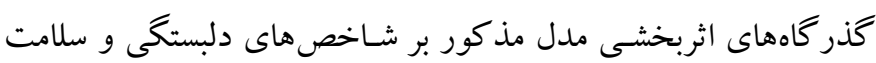

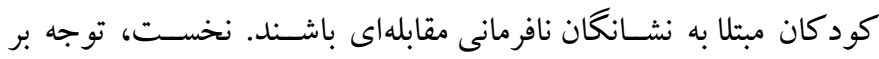

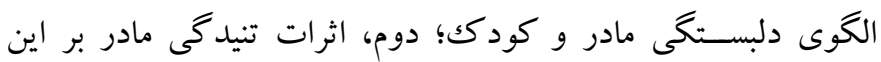
الكو؛ و سـوم، اثرات اين الكو بر شـرايط رابطه كودكك و مادر (Y) (I).

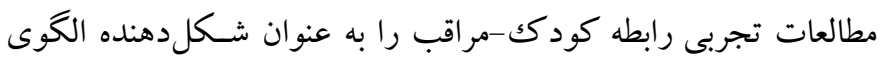

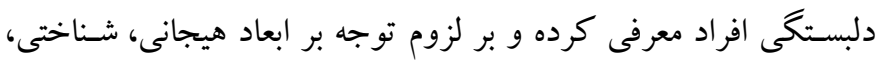
و رفتارى اين رابطه در مداخلات دلبستيخى محور تأكيد مى كنند (11).

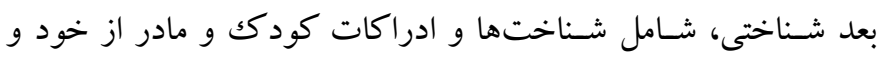

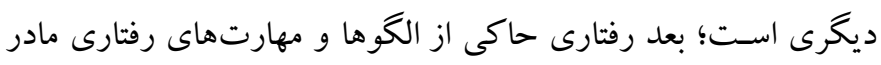

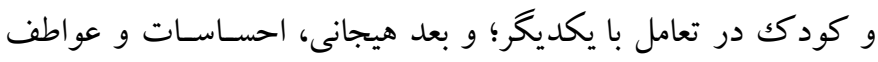

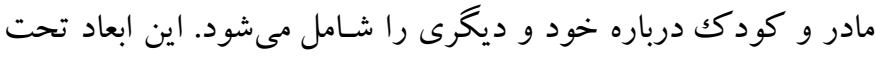

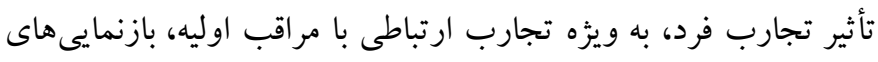

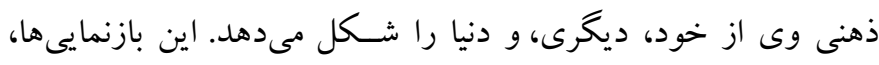

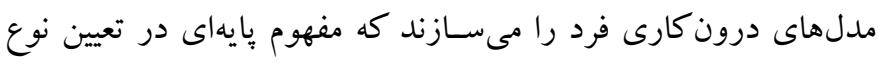

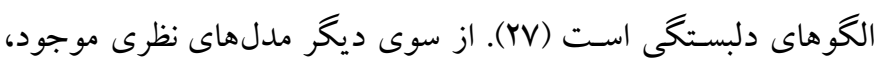

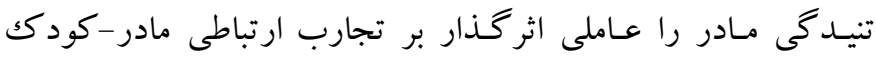

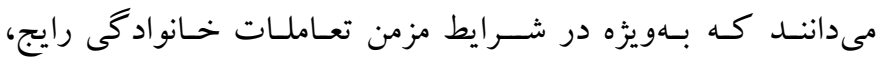

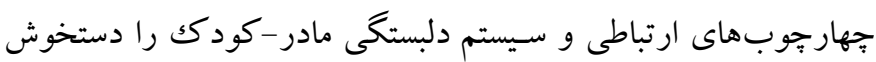

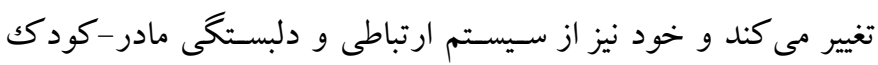

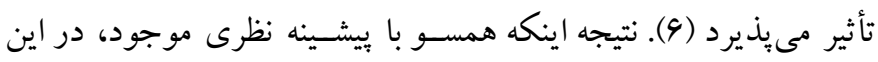

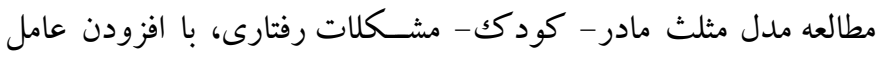

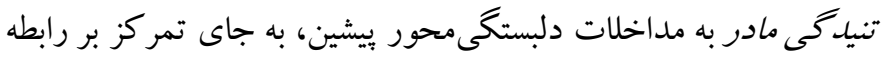




\section{References}

1. Honarparvaran N, Khatoni Z, Bagheri S, Namjoo F, Haronizadeh Z. Effectiveness of mother-child transactional analysis (TA) group therapy on attachment security in 6 to 10 years old boys suffering from oppositional defiant disorder. Journal of Applied Psychology. 2018; 11(4): 557-578. [Persian]. [Link]

2. Blumberg BM. Oppositional defiant disorder: a case report. J Psychiatry Psychiatr Disord. 2017; 1(4): 199211. [Link]

3. Association American Psychiatric. Diagnostic and statistical manual of mental disorders (DSM-5®). American Psychiatric Pub; 2013, p: 348. [Link]

4. Sadri M, Zare Bahramabadi M, Ghiasi M. Effectiveness of attachment-oriented therapy on the quality of attachment and social skills in children with oppositional defiant disorder. Quarterly Journal of Child Mental Health. 2016; 3(2): 21-30. [Persian]. [Link]

5. Lin X, Li L, Chi P, Wang Z, Heath MA, Du H, et al. Child maltreatment and interpersonal relationship among Chinese children with oppositional defiant disorder. Child Abuse Negl. 2016; 51: 192-202. [Link]

6. Jahanbakhsh M, Bahadori MH, Amiri SH, Jamshidi A. The effects of maternal attachment therapy with mothers in reducing hyper anxiety symptoms in daughters with attachment problems. Journal of Applied Psychology. 2012; 5(4): 26-41. [Persian]. [Link]

7. Crnic KA, Gaze C, Hoffman C. Cumulative parenting stress across the preschool period: relations to maternal parenting and child behaviour at age 5. Infant Child Dev. 2005; 14(2): 117-132. [Link]

8. Dehgani Arani F, Beshart MA. Effectiveness of a mother-child attachment-based intervention on health indices in mothers of children with chronic disease. Quarterly Journal of Health Psychology. 2014; 3(12): 42-57. [Persian]. [Link]

9. Ershad Sarabi R, Hashemi Razini H, Abdollahi MH. Comparing parental stress, parenting styles, and social problem solving in mothers of children with autism spectrum disorder, ADHD, and typically developing children. Quarterly Journal of Child Mental Health. 2018; 4(4): 165-179. [Persian]. [Link]

10.Khoramabadi R, Pouretemad HR, Tahmasian K, Chimeh N. A comparative study of parental stress in mothers of autistic and non-autistic children. Journal of Family Research. 2009; 5(3): 387-399. [Persian]. [Link]

11.King MG, Newnham K. Affective anomia: an interventional focus for attachment disorder. Australian Journal of Educational \& Developmental Psychology. 2008; 8: 103-113. [Link]
12.Dabrowska A, Pisula E. Parenting stress and coping styles in mothers and fathers of pre-school children with autism and Down syndrome. J Intellect Disabil Res. 2010; 54(3): 266-280. [Link]

13. Seyed Mousavi P, Mazaheri A, Pakdaman S, Heydari M. Effectiveness of attachment based therapy using video feedback on decreasing parental stress and externalizing problems of children. Contemporary Psychology, Biannual Journal of the Iranian Psychological Association. 2013; 8(1): 33-46. [Persian]. [Link]

14. Kheiry H, Salehi I, Soltani Shal R. The effectiveness of stress management training on marital satisfaction and parental stress in mothers with children with behavioral problems. Quarterly Journal of Child Mental Health. 2018; 4(4): 3-13. [Persian]. [Link]

15.Dirks E, Uilenburg N, Rieffe C. Parental stress among parents of toddlers with moderate hearing loss. Res Dev Disabil. 2016; 55: 27-36. [Link]

16. Hemati Alamdarloo G, Hosseinkhanzadeh AA, Arjmandi MS, Teymoori Asfichi MM, Taher M. The role of mothers' parenting style on prediction of behavior problems in preschool children with intellectual disability. Exceptional Education Journal. 2014; 3(125): 7-16. [Persian]. [Link]

17.McDaniel M, Slack KS. Major life events and the risk of a child maltreatment investigation. Child Youth Serv Rev. 2005; 27(2): 171-195. [Link]

18.Farzadfard SZ, Hooman HA. The role of child rearing training skills in reducing mothers stress and children,s behavioral problems. Journal of Developmental Psychology, Iranian Psychologists. 2008; 4(15): 277-292. [Persian]. [Link]

19. Nowruzpoor E, Janbozorgi M, Agah M, Falah M. The effectiveness of instructing transactional analysis on modifying perfectionism in mothers. Educational Psychology. 2014; 10(33): 155-168. [Persian]. [Link]

20.Eghbali M, Mousavi SV, Hakima F. The effectiveness of transactional analysis on mothers' parenting styles. Journal of Family Psychology. 2017; 3(2): 17-26. [Persian]. [Link]

21.Urquiza AJ, Blacker D. Parent-child interaction therapy for sexually abused children. In: GoodyearBrown P, editor. Handbook of child sexual abuse: identification, assessment, and treatment. John Wiley \& Sons, Ltd; 2011, pp: 279-296. [Link]

22.Esmaeilpour K, Mir A, Zareei A. Relationship between attachment problems and symptoms of oppositional defiant disorder in children. Quarterly Journal of Child Mental Health. 2016; 3(3): 73-83. [Persian]. [Link]

23. Thomas NL. 3 - Parenting children with attachment disorders. In: Levy TM, editor. Handbook of attachment interventions (Second Edition). San Diego: Academic Press; 2001, pp: 67-109. [Link] 
24.Purnell C. Attachment theory and attachment-based therapy. In: Green M, Scholes S, editors. Attachment and human survival. London: Karnac Books; 2004, pp: 1-14. [Link]

25.Berry JO, Jones WH. The parental stress scale: initial psychometric evidence. J Soc Pers Relat. 1995; 12(3): 463-472. [Link]

26. Ghasemzadeh S, Matbou Riahi M, Alavi Z, Hasanzadeh M. Effectiveness of family based intervention and play therapy on the parenting style of mothers and clinical symptoms in children with separation anxiety disorder. Journal of Research in Psychological Health. 2018; 11(4): 74-88. [Persian]. [Link]
27. Minaee A. Adaptation and standardization of Child Behavior Checklist, Youth Self-report, and teacher's report forms. Journal of Exceptional Children. 2006; 6(1): 529-558. [Persian]. [Link]

28. Achenbach TM, Dumenci L, Rescorla LA. Ratings of relations between DSM- IV diagnostic categories and items of the CBCL/G-18, TRF, and YSR. Burlington, VT: University of Vermont; 2001, pp: 1-9. [Link]

29. Ghanbari S, Khodapanahi MK, Mazaheri MA, Gholamali Lavasani M. The effectiveness of attachment based parent training on increasing maternal caregiving quality in preschool anxious children. Journal of Family Research. 2014; 9(4): 407-426. [Persian]. [Link] 